\title{
Purification and characterization of angiotensin-converting enzyme (ACE) from sheep lung
}

\author{
Fatih Aydin $^{1} \cdot$ Vedat Turkoglu $^{1} \cdot$ Zehra Bas $^{2}$
}

Received: 28 January 2021 / Accepted: 21 May 2021 / Published online: 4 June 2021

(c) The Author(s), under exclusive licence to Springer Nature B.V. 2021

\begin{abstract}
Angiotensin-converting enzyme (ACE, EC 3.4.15.1) in the renin-angiotensin system regulates blood pressure by catalyzing angiotensin I to the vasoconstrictor angiotensin II. In this study, the ACE was purified and characterized from sheep lung. The kinetic properties of the ACE were designated. The inhibition effect of captopril, a specific ACE inhibitor, was determined. ACE was purified from sheep lung using the affinity chromatography method in one step. NHS-activated Sepharose 4 Fast Flow as column filler and lisinopril as a ligand in this method used. The molecular weight and purity of ACE were designated using the SDS-PAGE method. Optimum temperature and optimum $\mathrm{pH}$ were found for purified ACE. $\mathrm{K}_{\mathrm{M}}$ and $\mathrm{V}_{\max }$ values from Lineweaver-Burk charts determined. The inhibition type, $\mathrm{IC}_{50}$, and $\mathrm{K}_{\mathrm{i}}$ values of captopril on purified ACE were identified. ACE was 6405 -fold purified from sheep lung by affinity chromatography in one step and specific activity was $16871 \mathrm{EU} / \mathrm{mg}$ protein. The purity and molecular weight of ACE were found with SDS-PAGE and observed two bands at around $60 \mathrm{kDa}$ and $70 \mathrm{kDa}$ on the gel. Optimum temperature and optimum $\mathrm{pH}$ were designated for purified ACE. Optimum temperature and $\mathrm{pH}$ were found as $40{ }^{\circ} \mathrm{C}$ and $\mathrm{pH} 7.4$, respectively. $\mathrm{V}_{\max }$ and $\mathrm{K}_{\mathrm{M}}$ values were calculated to be 35.59 ( $\mu \mathrm{mol} /$ $\min ) \cdot \mathrm{mL}^{-1}$ and $0.18 \mathrm{mM}$, respectively. $\mathrm{IC}_{50}$ value of captopril was found as $0.51 \mathrm{nM}$. The inhibition type of captopril was determined as non-competitive from the Lineweaver-Burk graph and the $\mathrm{K}_{\mathrm{i}}$ value was $0.39 \mathrm{nM}$. As a result, it was observed in this study that the ACE enzyme can be successfully purified from sheep lungs in one step. Also, it was determined that captopril, which is a specific ACE inhibitor, has a significant inhibitory effect with a very low $\mathrm{IC}_{50}$ value of $0.51 \mathrm{nM}$.
\end{abstract}

Keywords Angiotensin-converting enzyme $(\mathrm{ACE}) \cdot$ Characterization $\cdot$ Purification

\section{Introduction}

Hypertension is one of the most important health problems leading to coronary heart disease, myocardial infarction, and kidney disease [1]. Angiotensin-converting enzyme (dipeptidyl carboxypeptidase, EC 3.4.15.1; ACE) regulates blood pressure by converting the decapeptide angiotensin I to octapeptide angiotensin II, a potent vasoconstrictor, and inactivates the vasodilator bradykinin compound [2]. The enzyme hydrolyzes the angiotensin I, bradykinin, [3] but also the important hemoregulatory peptide, Acetyl-Ser-Asp-LysPro [4], as well angiotensin 1-7 [5] and substance P [6]. Also,

Zehra Bas

zehrabas@yyu.edu.tr

1 Department of Chemistry, Faculty of Science, Van YüzüncüYıll University, Van, Turkey

2 Department of Nutrition and Dietetics, Faculty of Health Sciences, Van Yüzüncü Y1l University, 65080 Van, Turkey the haemoregulatory peptide $\mathrm{N}$-acetyl-Ser-Asp-Lys-Pro is a specific and natural substrate of the $\mathrm{N}$-terminal active site of human ACE [4].

ACE is a zinc metallopeptidase that belongs to the dipeptidyl carboxypeptidase family. The human ACE enzyme has two functional $\mathrm{N}$ and $\mathrm{C}$ domains, each with an active site by a zinc ion binding site. Zinc is an important component in the catalytic binding site of ACE [7]. Helix 13 includes the canonical HEXXH zinc-connecting motif, using His 387 and His 383 along with Glu 411 on helix 14. The active site of ACE combines with several other stabilizing residues using the bound zinc [7]. The substrate connects the zinc by replacing it with the water compound connected to zinc. Following, the water compound combines with nearby Glu 384, causing polarization between the positive zinc ion and the negative glutamate carboxylate group [8]. This increases the nucleophilicity of water oxygen, triggering an assault on the peptide carbonyl carbon substrate. The proton taken up by the active site glutamate is sent to the nitrogen, presumably 
forming a tetrahedral gem-diolate intermediate with the aid of Tyr 523. The dipeptide product protonated form consists of cleavage of the C-N bond. [7]. The residuary peptide substrate is balanced by hydrogen bond interplays between Ala 354 and the new terminal amide, His 513 and His 353 by the secondary carbonyl group, and Lys 511 and Tyr 520 and the terminal carboxylate [9].

The ACE enzyme is a high molecular weight integral membrane protein situated on the lumen surface of the cell membrane. There are two forms of ACE enzyme: the somatic form, which is abundant in the endothelial surface of the lung vessels, and a smaller germinal form found only in the testis $[10,11]$. The somatic isoform has a molecular mass that varies from 130 to $180 \mathrm{kDa}$ and was described in the endothelial [12], epithelial, mesangial, and neuronal cells [13, 14], and in the subsequent tissues as intestine, lung, kidney, pancreas, heart, placenta, and liver [15-17]. The germinal ACE of $90-100 \mathrm{kDa}$ is similar to the C-terminal part of the endothelial ACE. Germinal ACE is limited solely to the testis found in germinal cells during the maturation of spermatogenesis [18]. Soluble ACE forms were described in urine and the ileal, seminal, and amniotic fluids [19-21], and plasma [22].

In the literature, $\mathrm{N}$-domain ACE was described in ileal fluid and urine by Deddish et al. [19] and Casarini et al. [21, 23]. In urine, Casarini et al. [21, 23] observed two ACE isoforms by molecular weights of 65 and $190 \mathrm{kDa}$ (N-domain ACE) in the urine of healthy subjects, and two isoforms of 65 and $90 \mathrm{kDa}$ (both $\mathrm{N}$-domain ACE) in the urine of patients with hypertension differing from the enzyme described by Deddish et al. also N-domain ACE from human ileum fluid with a molecular weight of $108 \mathrm{kDa}$ [19]. Marques et al. found the same profile in the urine of Wistar-Kyoto and spontaneously hypertensive rats as described for the urine of healthy and patients with hypertension, and suggested the $90 / 80 \mathrm{kDa}$ ACE isoforms as a likely genetic marker of hypertension [24].

ACE interacts simultaneously with the RAS and the kallikrein-kinin system, separating the C-terminal dipeptide from Angiotensin I and bradykinin. ACE has been observed to play a very important role in the balance between the vasodilatory properties of bradykinin and the vasoconstrictor features of angiotensin II. An increase in ACE activity disrupts this delicate balance, activates the vasoconstrictor angiotensin II and reduces the vasodilator bradykinin. ACE inhibitors reduce high blood pressure by reducing angiotensin II formation and increasing the bradykinin compound. Thus, these inhibitors restore this balance in hypertensive patients [25-27].

The affinity chromatography method is very sensitive and reduces the purification steps to a single step. Several thousand folds of purification can be made using this highly selective method. Therefore, the affinity chromatography method is generally used in purification processes [28]. The ACE enzyme was purified with lisinopril—affinity chromatography from human plasma [29], pig kidney [30], adult houseflies (Musca domestica) [31], swine serum [32], and pig lung [33]. In this work, NHS-activated Sepharose 4 Fast Flow as column filler in affinity chromatography method utilized. Lisinopril, a specific ACE inhibitor, as ligand utilized.

In this work, the ACE enzyme was purified from sheep lung with affinity chromatography and characterized. Optimum temperature and optimum $\mathrm{pH}$ of the ACE were found. $\mathrm{K}_{\mathrm{M}}$ and $\mathrm{V}_{\max }$ values determined. Until now, the ACE enzyme has not been purified from sheep lung in the literature. $\mathrm{IC}_{50}$ value, the inhibition type, and the $\mathrm{K}_{\mathrm{i}}$ value of captopril on purified ACE were found.

\section{Materials and methods}

\section{Materials}

Sodium tetraborate $\left(\mathrm{Na}_{2} \mathrm{~B}_{4} \mathrm{O}_{7} \cdot 10 \mathrm{H}_{2} \mathrm{O}\right)$, HepesNa, Coomassie Brillant Blue R-250, N-[3-(2-Furyl)acryloyl]-L-phenylalanyl-glycyl-glycine (FAPGG), lisinopril, and Coomassie Brillant Blue G-250 were bought from Sigma-Aldrich. NHS-activated Sepharose 4 Fast Flow was obtained from GE Healthcare Life Sciences. Captopril was purchased from Alfa Aesar.

\section{Obtain of the sheep lung}

Healthy sheep lungs, which were slaughtered in the slaughterhouse, were brought to the laboratory. Approximately $20 \mathrm{~g}$ of tissue was cut from different areas of the lung. This section was cut into small cubic pieces with a scalpel. The disrupted lung was added to $50 \mathrm{mM}$ Tris (pH 7.4) buffer. This mix was subjected to disintegration for 3 min with the help of a mixer. Meanwhile, ice was placed around the mixer to prevent it from heating. The homogenate obtained was applied for $3 \mathrm{~min}$ in an ultrasonic homogenizer for further disintegration. Then, the mixture in the beaker was placed in the centrifuge tubes and centrifuged in a cooled centrifuge device at $8500 \mathrm{xg}$ at $+4{ }^{\circ} \mathrm{C}$ for $1 \mathrm{~h}$. This was done several times. After centrifugation, the liquid from the top of the tube was taken and stored in the freezer for use in the purification process.

\section{Affinity chromatography method}

NHS-activated Sepharose 4 Fast Flow $(25 \mathrm{~mL})$ in $100 \%$ isopropanol was activated using the procedure of the manufacturer. To prepare the column, first, the gel was washed with $1 \mathrm{mM}$ cold $\mathrm{HCl}$. Second, a coupling tampon $(5 \mathrm{mM}$ of Lisinopril, $0.2 \mathrm{M}$ of $\mathrm{NaHCO}_{3}$, and $0.5 \mathrm{M}$ of $\mathrm{NaCl}$ ) was added 
to the affinity gel. Completion of the reaction was left at $4{ }^{\circ} \mathrm{C}$ overnight. The gel was then kept in $0.1 \mathrm{M}$ Tris- $\mathrm{HCl}(\mathrm{pH} 8.5)$ for several hours to prevent nonreacted groups on the affinity gel. Following, the gel was washed with $0.1 \mathrm{M}$ acetate tampon (pH 4.5) and 0.1 M Tris-HCl tampon (pH 8.5). This process was done three times. Then, the affinity gel was suspended with an equilibration tampon $(20 \mathrm{mM}$ of Tris and $0.3 \mathrm{M}$ of $\mathrm{NaCl}, \mathrm{pH} 8.0$ ).

The suspended affinity gel was packaged in a column $(1 \mathrm{x} 10 \mathrm{~cm})$ with the equilibration tampon $(20 \mathrm{mM}$ of Tris and $0.3 \mathrm{M}$ of $\mathrm{NaCl}, \mathrm{pH} 8.0$ ). The flow rates for washing and equilibration were determined using a peristaltic pump to $40 \mathrm{~mL} / \mathrm{h}$. After, the sheep lung was loaded onto the NHSactivated Sepharose 4 Fast Flow affinity column, and the column was cleaned by the equilibrium tampon. Subsequently, cleaning of the gel was continued until the absorbance was 0.1 at $280 \mathrm{~nm}$. Following, sodium borate tampon $(50 \mathrm{mM}$ of $\mathrm{Na}_{2} \mathrm{~B}_{4} \mathrm{O}_{7} \cdot 10 \mathrm{H}_{2} \mathrm{O}, \mathrm{pH} 9.0$ ) was given to the column. The elution was then taken as $2.5 \mathrm{~mL}$ fractions. The ACE activity in the fractions was determined spectrophotometrically at $345 \mathrm{~nm}$. The activity-containing tubes were pooled. All of the procedures were done at $4{ }^{\circ} \mathrm{C}[34,35]$.

\section{ACE Activity determination}

The ACE activity was measured spectrophotometrically as the decrease in the absorbance at $35^{\circ} \mathrm{C}$ and $345 \mathrm{~nm}$ according to the method of Holmquist [36]. The assay cuvette contained $50 \mathrm{mM}$ HepesNa tampon $\left(10 \mu \mathrm{M} \mathrm{ZnCl}_{2}, 0.3 \mathrm{M}\right.$ $\mathrm{NaCl}, \mathrm{pH} 7.5)$ and $1 \mathrm{mM}$ FAPGG. One unit of activity was identified as the quantity of ACE that produces a $\Delta A_{345} / \mathrm{min}$ of $1.0[33,36]$.

\section{Protein determination}

The protein concentrations of the purified fractions and the lung homogenate were designated using Coomassie Brillant Blue G-250 dye solution at $595 \mathrm{~nm}$ with the Bradford procedure. In this method, bovine serum albumin was utilized as the standard protein solution. The standard chart was drawn with the values found [37].

\section{Determination of purity and molecular weight of ACE with SDS-PAGE method}

Purity and molecular weight purity of the ACE, SDS-PAGE were determined according to Laemmli's method. The acrylamide concentrations of the separating and stacking and gels were prepared as $10 \%$ and $4 \%$, respectively. Also, both the separating and stacking gels were found to have $1 \%$ SDS. After the process of running the proteins in the electrophoresis process was finished, the gel was removed. The gel was stained for $2 \mathrm{~h}$ in $0.025 \%$ Coomassie Brillant Blue
R-250 dye solutions including $7 \%$ acetic acid, $40 \%$ methanol, and bidistilled water. The gel was taken from the dye solution. The gel was first washed in the first wash solution (10\% acetic acid, $50 \%$ methanol, and $40 \%$ bidistilled water). It was then washed in the second wash solution (7\% acetic acid, $5 \%$ methanol, and $88 \%$ bidistilled water). The photo of the protein bands on the gel obtained was taken [38].

\section{Optimum temperature determination}

The optimum temperature of ACE purified from sheep lung was found using a constant temperature circulation bath. HEPES buffer, ACE, and FAPGG substrate to be used for activity measurement were added into the cuvette, mixed with a vortex and the first absorbance was taken in the spectrophotometer. Then the sample temperature was left in the adjusted constant temperature circulation bath. At the end of thirty minutes, it was removed from the constant temperature circulation bath and the final absorbance was read in the spectrophotometer. Measurements were made between $20-60{ }^{\circ} \mathrm{C}$ at $5{ }^{\circ} \mathrm{C}$ intervals. To designate the optimum temperature, the ACE activity was assayed at $345 \mathrm{~nm}$ in $50 \mathrm{mM}$ HEPES tampon at the distinct temperature intervals in the range from 20 to $60{ }^{\circ} \mathrm{C}$. The temperature was performed with a Grant bath (model 6G).

\section{Optimum pH determination}

HEPES buffers with pH 6.8, 7.0, 7.2, 7.4, 7.6, 7.8, 8.0, 8.2 were prepared to determine the optimum $\mathrm{pH}$ of ACE purified from sheep lung. ACE activities were measured individually using buffers at this $\mathrm{pH}$. The same method was used for activity measurement. For the optimum $\mathrm{pH}$ designation, the ACE activity was performed in $50 \mathrm{mM}$ HEPES tampon over the $\mathrm{pH}$ ranges $6.8-8.2$. The activity measurement was made at 0.2 unit intervals between $\mathrm{pH}$ values of 6.8-8.2.

\section{In vitro inhibition effect of captopril on ACE activity}

The inhibition effect of captopril on ACE purified from sheep lung was explored. For this, distinct concentrations of the active substances were joined to the measurement cuvette ( $100 \mu \mathrm{L}$ enzyme solution, $50 \mathrm{mM}$ HepesNa, $10 \mu \mathrm{M}$ $\mathrm{ZnCl}_{2}, 0.3 \mathrm{M} \mathrm{NaCl}, 1 \mathrm{mM}$ FAPGG,) for determination of the concentration interval, and ACE activities were measured. Percentage activity vs active substances concentration was plotted. The $\mathrm{IC}_{50}$ value of captopril was found from the equations of the inhibition plots. To plot Lineweaver-Burk graph and designate the inhibition type, five distinct concentrations of FAPGG and three different concentrations for captopril were used [39]. 


\section{Results and discussion}

In the present work, ACE was purified and characterized from sheep lung. NHS-activated Sepharose 4 Fast Flow was utilized as a column filling substance in the affinity chromatography method (Fig. 1). It was purified 6405 fold in one-step ACE with affinity chromatography method and its specific activity was designated as $16871 \mathrm{EU} / \mathrm{mg}$ protein (Table 1). In a work, ACE was purified approximately 7000 times from human lung tissue [40]. In a work by Erickson et al. ACE was purified 4500 fold from rat intestinal mucosa after affinity chromatography and gel filtration with lisinopril-sepharose. The specific activity of the purified ACE enzyme was calculated as $65 \mathrm{U} / \mathrm{mg}$ protein with benzoylGly-His-Leu used as a substrate [41]. The purification factor of ACE enzyme purified from adult house flies (M. domestica) by lisinopril-sepharose affinity column chromatography was calculated as 709 [31]. In another work, ACE was 1588 -fold purified from canine testes by lisinopril—affinity chromatography [35]. ACE was 308-fold purified from pig lung and the specific activity was $37 \mathrm{U} \mathrm{mg}^{-1}$ [42]. Compared to alike works, the high purification coefficient in our work proves a successful purification in one step.

Angiotensin-converting enzyme (ACE) in a membranebound form in epithelial or neuroepithelial cells, endothelial cells, heart, lung, brain, kidney, and testes; It is a divalent

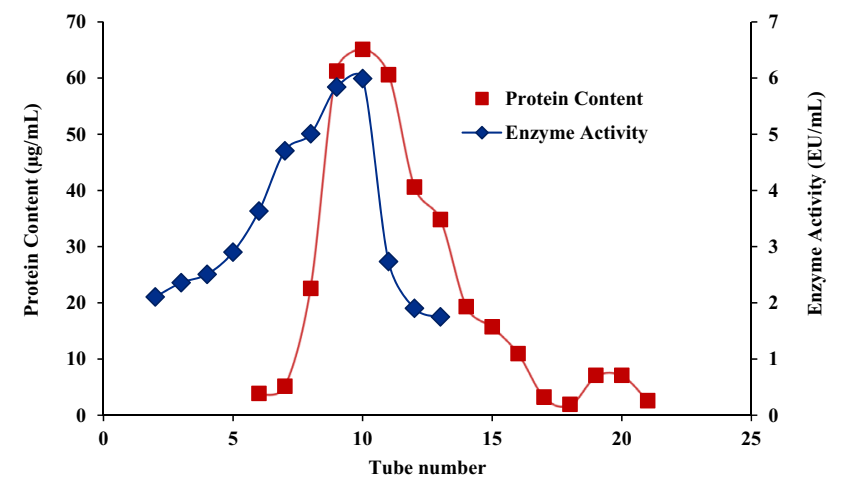

Fig. 1 Purification of the ACE enzyme with NHS-activated Sepharose 4 Fast Flow affinity chromatography column dipeptidyl carboxyl metallopeptidase present in a soluble form in the blood, serum, plasma, seminal and lymph fluid, cerebrospinal fluid and many-body fluids [43, 44]. In most of the studies, chemicals such as detergents have been used to purify the membrane-bound ACE enzyme. For example; Triton X-100 was utilized to be a detergent to purify the ACE enzyme from human lung tissue [40]. Detergent and protease inhibitors were used when purifying the ACE enzyme in canine testicles [18]. Triton X-100 was used when purifying the ACE enzyme from the ostrich (Struthio camelus) lung [45]. In our work, sheep lung homogenate was prepared with tris buffer ( $\mathrm{pH}$ 7.4). As a result, soluble forms of ACE pass into the solution medium while preparing the lung homogenate. Soluble forms of ACE from sheep lung homogenate were purified by affinity chromatography. Therefore, in this study, a successful purification was performed in one step without using detergents such as Nonidet P-40, Triton X-100, trypsin, and protease inhibitors. In this case, it provided us a great advantage in terms of both time and costs while purifying.

In the present work, ACE was purified from sheep lung using affinity chromatography, in which lisinopril used as ligand and NHS-activated Sepharose 4 Fast Flow utilized to be column packing substance. This ligand is a specific ACE inhibitor. Sodium tetraborate ( $\mathrm{pH}$ 9) tampon was used as elution tampon and prosperous purification was performed in a one-step method. In some studies, ACE was purified from rabbit lung, human plasma, pig kidney, and pig striatum with lisinopril-affinity chromatography by Sepharose CL-4B, column packing substance. Hepes ( $\mathrm{pH}$ 7.5) was utilized to be the elution tampon and $10 \mu \mathrm{M}$ lisinopril was joined to Hepes tampon. Dialysis was performed against EDTA (pH7.5) tampon for 14 days to separate the lisinopril in the eluates [29, 46]. In this work, dialysis was not required since lisinopril was not joined to the elution tampon. Therefore, significantly high ACE activity was found in elutions that supply important advantages in both costs of the process and time.

Studies have shown that there are two forms of eACE. There are two isoenzymes, the first is the somatic ACE (130-180 kDa) found in somatic tissues like the kidney and lung, and the second is the testicular ACE (90-110 kDa), which includes solely one catalytic domain, which is the same as the C-terminal domain of the somatic ACE [47,

Table 1 Purification scheme of angiotensin-converting enzyme (ACE) purified from sheep lung

\begin{tabular}{lllccccc}
\hline Purificaton steps & Activity (EU/mL) & $\begin{array}{l}\text { Total } \\
\text { volume } \\
(\mathrm{mL})\end{array}$ & Protein $(\mathrm{mg} / \mathrm{mL})$ & Total protein $(\mathrm{mg})$ & $\begin{array}{l}\text { Toplam } \\
\text { activity } \\
\text { (EU) }\end{array}$ & $\begin{array}{l}\text { Spevific } \\
\text { activity (EU/ } \\
\text { mg) }\end{array}$ & $\begin{array}{l}\text { Yield }(\%) \\
\text { Purifi- } \\
\text { cation } \\
\text { factor }\end{array}$ \\
\hline $\begin{array}{l}\text { Sheep lung } \\
\begin{array}{l}\text { NHS-activated Sepha- } \\
\text { rose 4 fast flow chro- } \\
\text { matography }\end{array}\end{array}$ & 64.475 & 50 & 24.477 & 1223.85 & 3223.75 & 2.634 & 100 \\
\hline
\end{tabular}


48]. For instance; the molecular weight of the ACE enzyme purified from adult house flies (M. domestica) was determined by SDS-PAGE to be $67 \mathrm{kDa}$ [31]. The ACE enzyme was purified from frog ovaries with affinity chromatography by extraction with detergent and trypsin. The molecular weight of the ACE enzyme extracted with both detergent and trypsin was determined to be $150 \mathrm{kDa}$ [49]. The molecular weight of the ACE enzyme purified from rat intestinal mucosa was found as $160 \mathrm{kDa}$ by SDS-PAGE [23]. In a work conducted by El-Dorry et al., The molecular weight of the ACE enzyme purified from rabbit testes was designated as $100 \mathrm{kDa}$ [50]. Casarini et al. [21] characterized isoforms of the ACE N-domain with 65 and $90 \mathrm{kDa}$. This group has publications on mesangial cells, urine, tissue from Wistar and SHR mice. Andrade et al. did a spectroscopic and structural analysis of somatic and $\mathrm{N}$-domain ACE isoforms from mesangial cells detecting differences between these enzymes [51]. I another study the same group described sheddases able to liberate 65 and $90 \mathrm{kDa} \mathrm{ACE}$ isoforms in mesangial cells [52].

Also, in our previous studies, the molecular weight of the ACE enzyme purified from human plasma was found to be 60 and $70 \mathrm{kDa}[53,54]$. In our work, purity and molecular weight of the ACE enzyme purified from sheep lungs were designated by SDS-PAGE, and two bands, $60 \mathrm{kDa}$ and $70 \mathrm{kDa}$, were observed on the gel (Figs. 2 and 3). Since the ACE enzyme has two isoenzymes, distinct molecular weights were determined in distinct tissues that were purified.

Biochemical parameters were found to further characterize the ACE enzyme purified from sheep lung. Measurements were made for the purified ACE enzyme at 5 different FAPGG concentrations. Then, the Lineweaver-Burk plot was drawn using these values (Fig. 4). From this graph, $\mathrm{V}_{\text {max }}$ and $\mathrm{K}_{\mathrm{M}}$ values were calculated as $35.59(\mu \mathrm{mol} / \mathrm{min})$. $\mathrm{mL}^{-1}$ and $0.18 \mathrm{mM}$, respectively (Table 2 ). In a study by Quassinti et al. the $\mathrm{V}_{\max }$ and $\mathrm{K}_{\mathrm{M}}$ values of the FAPGG substrate for ACE purified from pig serum were determined to be $0.061 \pm 0.0014 \mathrm{nmol} / \mathrm{min}$ and $0.793 \pm 0.052 \mathrm{mM}$, respectively [32]. In another work, FAPGG substrate for ACE purified from frog ovaries (Rana esculenta) was used. The $\mathrm{V}_{\text {max }}$ and $\mathrm{K}_{\mathrm{M}}$ values were calculated to be $0.915 \pm 0.04 \mathrm{nmol} /$ $\min$ and $0.608 \pm 0.07 \mathrm{mM}$, respectively [49]. For the ram epididymal fluid form of the germinal ACE enzyme derived from the sperm membrane, the $\mathrm{K}_{\mathrm{M}}$ and $\mathrm{V}_{\max }$ values of the FAPGG substrate were calculated as $0.18 \mathrm{mM}$ and $34 \mu \mathrm{moles} /(\min . \mathrm{mg})$ [55].

In our work, the optimum $\mathrm{pH}$ and optimum temperature range at which the activity of ACE purified from sheep lung is the highest was determined. Optimum $\mathrm{pH}$ and optimum temperature for ACE purified from sheep lung were found to be pH 7.4 and $40{ }^{\circ} \mathrm{C}$, respectively (Fig. 5 and Fig. 6). Similarly, in our previous work, the optimum $\mathrm{pH}$ value of

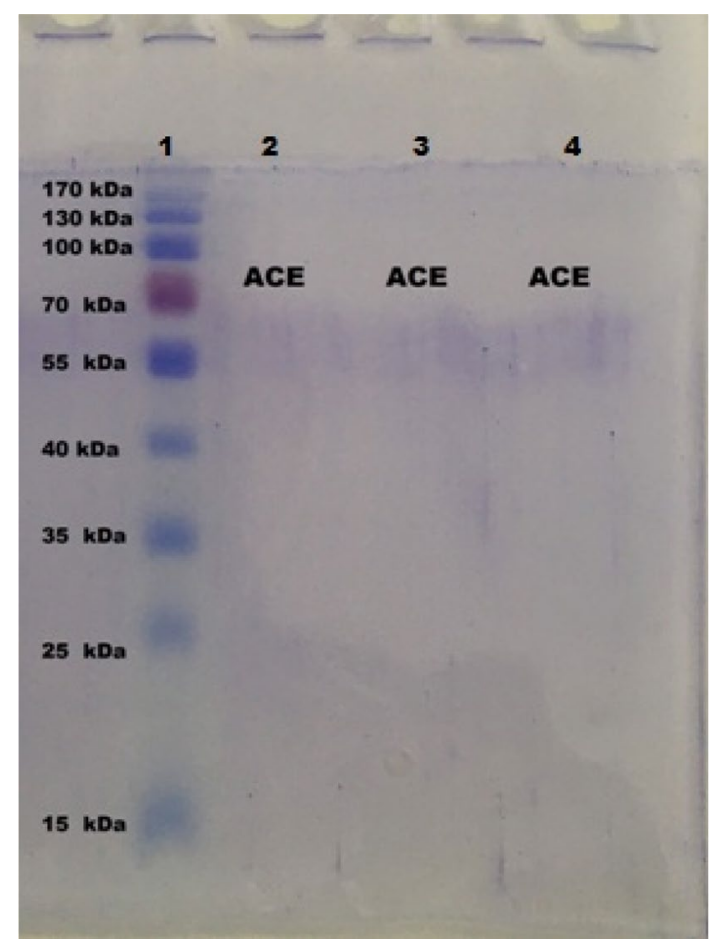

Fig. 2 SDS-polyacrylamide gel electrophoresis of ACE purified by affinity chromatography. Lane 1: standard proteins (fermentas unstained protein ladder SM0671). Lanes 2, 3, and 4: purified angiotensin-converting enzyme (ACE) from sheep lung

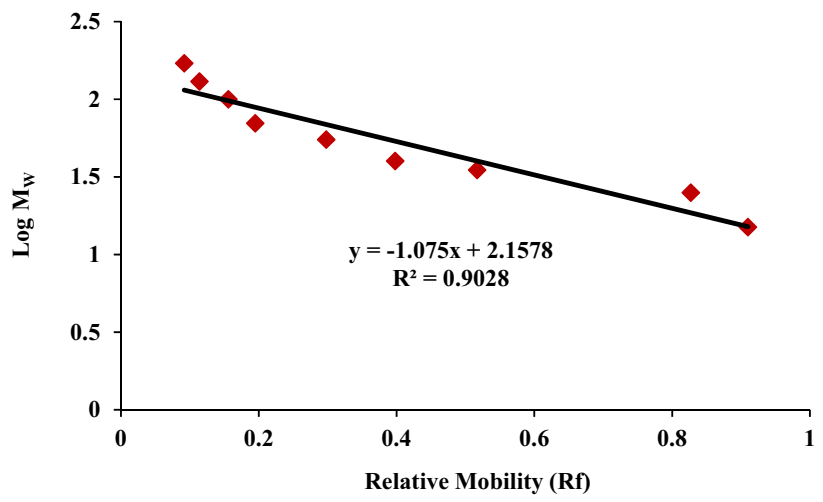

Fig. 3 Standard relative mobility $\left(\mathrm{R}_{\mathrm{f}}\right)-\log _{\mathrm{W}}$ graph of ACE using SDS-PAGE

the ACE enzyme purified from human plasma was found between 7.4 and the optimum temperature between $35-40{ }^{\circ} \mathrm{C}$ [56]. In another work, ACE was purified from rabbit lung and the optimum temperature was $37^{\circ} \mathrm{C}$ and the optimum $\mathrm{pH}$ was 8.0-8.3 [57].

Here, the inhibition effect of captopril, a specific ACE inhibitor, on purified from sheep lung investigated. The inhibitory effect of captopril on ACE activity purified using different concentrations of captopril was measured. The 


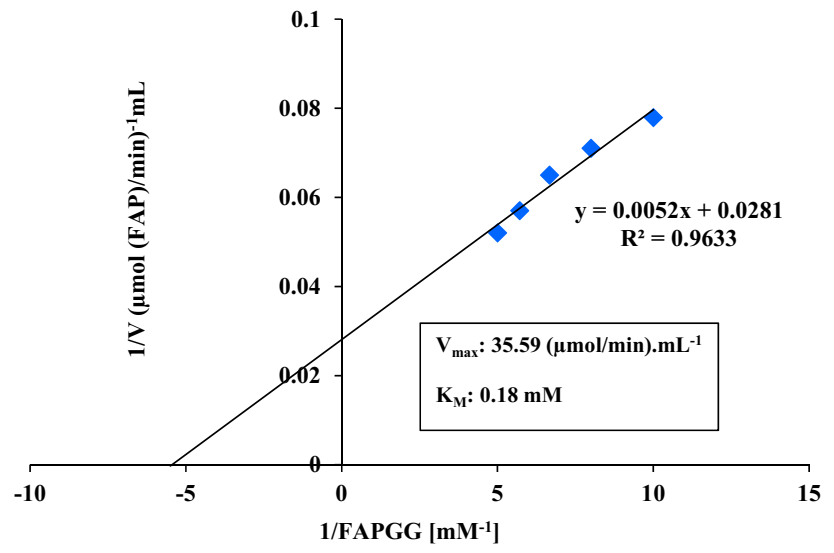

Fig. 4 Lineweaver-Burk graph with five different substrate concentrations (FAPGG) used for the designation of $\mathrm{V}_{\max }$ and $\mathrm{K}_{\mathrm{M}}$ values

experiments were repeated three times and the experimental error bars were plotted (Fig. 7). \% activity versus inhibitor plotted (Fig. 8). Also, measurements were made on the ACE activity at 3 different captopril and 5 different FAPGG substrate concentrations. After, the Lineweaver-Burk graph was drawn with these values (Fig. 9). The inhibition type, $\mathrm{Ki}$, and $\mathrm{IC}_{50}$ values of captopril on purified ACE from these graphs were determined. $\mathrm{IC}_{50}$ value of captopril was found as $0.51 \mathrm{nM}$. The inhibition type of captopril was found as non-competitive from the Lineweaver-Burk chart and the $\mathrm{K}_{\mathrm{i}}$ value was $0.39 \mathrm{nM}$ (Table 2). In our previous study, the inhibition effect of lisinopril on ACE purified from human plasma was studied and the $\mathrm{IC}_{50}$ value was found to be $0.781 \mathrm{nM}$ [58]. In many studies, it has been observed that thiol-containing inhibitors such as captopril can exhibit noncompetitive inhibitory effects by forming strong bonds with zinc near the enzyme's active site. In a study, two inhibitors containing thiol groups [captopril or SQ 14225 and 2-(2'-hydroxyphenyl)-3-(3-mercaptopropanoyl)-4-thiazolidine carboxylic acid or SA 446] showed both a mixed

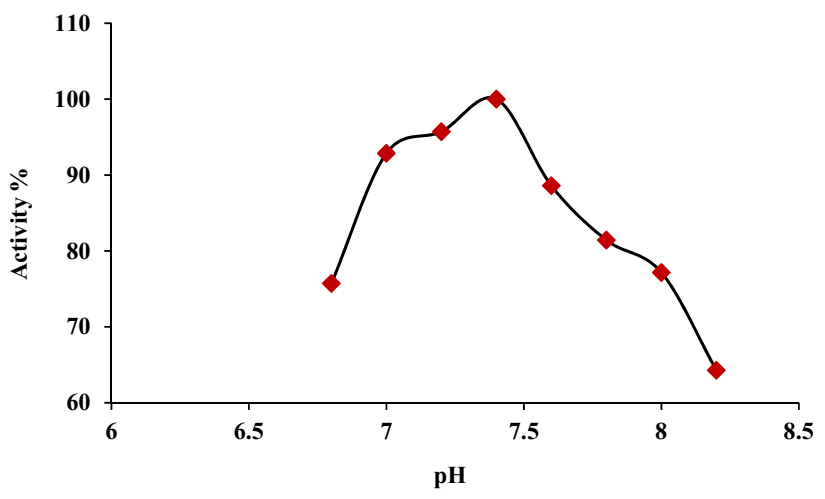

Fig. 5 The effect of $\mathrm{pH}$ on the activity of sheep lung ACE

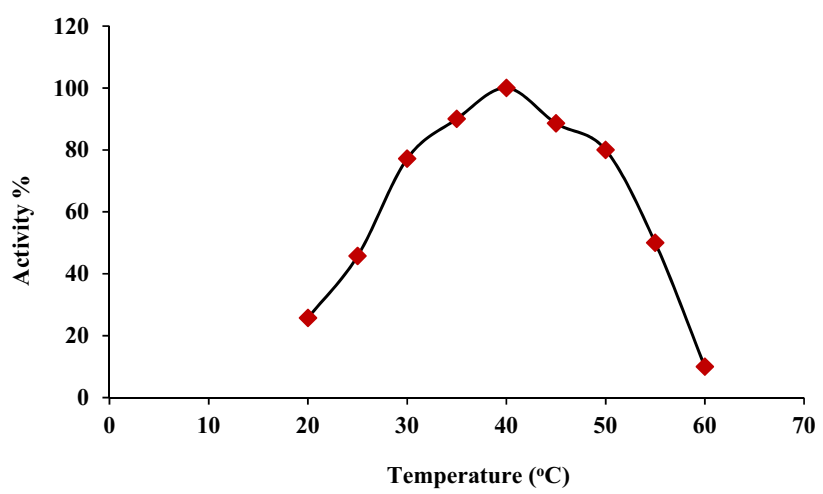

Fig. 6 The effect of temperature on the activity of sheep lung ACE

competitive and non-competitive inhibitory effect on the rat lung ACE enzyme [59]. At the same time, although inhibitors such as captopril, enalaprilat, and ramiprilat are defined as competitive inhibitors, they have shown a mixed and noncompetitive inhibitory effect in some studies [60].

Herein, ACE was purified and characterized for the first time from sheep lung by affinity chromatography

Table 2 Comparison scheme of molecular weight, optimum $\mathrm{pH}$, optimum temperature, $\mathrm{V}_{\max }$, and $\mathrm{K}_{\mathrm{M}}$ values of purified angiotensin-converting enzyme (ACE)

\begin{tabular}{|c|c|c|c|c|c|c|}
\hline Purification & The molecular weight & Optimum pH & $\begin{array}{l}\text { Optimum } \\
\text { tempera- } \\
\text { ture }\end{array}$ & $\mathrm{K}_{\mathrm{M}}$ values & Vmax values & References \\
\hline Sheep lung & 60 and $70 \mathrm{kDa}$ & 7.4 & $40^{\circ} \mathrm{C}$ & $0.18 \mathrm{mM}$ & $35.59(\mu \mathrm{mol} / \mathrm{min}) \mathrm{mL}^{-1}$ & This study \\
\hline Human plasma & 60 and $70 \mathrm{kDa}$ & 7.4 & $35-40{ }^{\circ} \mathrm{C}$ & - & - & {$[56]$} \\
\hline Rabbit lung & - & $8.0-8.3$ & $37^{\circ} \mathrm{C}$ & $1.8 \mathrm{mM}$ & $0.42 \mu \mathrm{mol} / \mathrm{min}$ & {$[57]$} \\
\hline $\begin{array}{l}\text { Adult houseflies (Musca domes- } \\
\text { tica) }\end{array}$ & $67 \mathrm{kDa}$ & - & - & $235 \pm 21 \mu \mathrm{M}$ & $88 \pm 4$ units $/ m g$ protein & {$[31]$} \\
\hline Swine serum & $180 \mathrm{kDa}$ & - & - & $0.793 \pm 0.052 \mathrm{mM}$ & $0.061+0.0014 \mathrm{nmol} / \mathrm{min}$ & {$[32]$} \\
\hline Frog ovary (Rana esculenta) & $150 \mathrm{kDa}$ & $7-8.5$ & $50^{\circ} \mathrm{C}$ & $0.608 \pm 0.07 \mathrm{mM}$ & $0.915 \pm 0.04 \mathrm{nmol} / \mathrm{min}$ & [49] \\
\hline $\begin{array}{l}\text { Sperm membrane-derived ger- } \\
\text { minal ACE }\end{array}$ & $94 \mathrm{kDa}$ & - & - & $0.18 \mathrm{mM}$ & 34 moles/(min.mg) & {$[55]$} \\
\hline
\end{tabular}




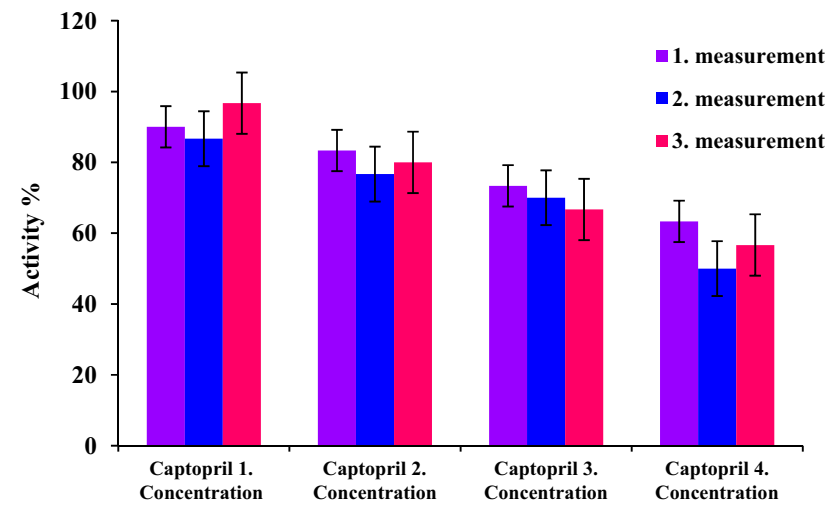

Fig. $7 \%$ ACE activity determined using different concentrations of Captopril. Standard error bars representing Captopril concentrations versus activity $\%$ measurements performed in triplicate

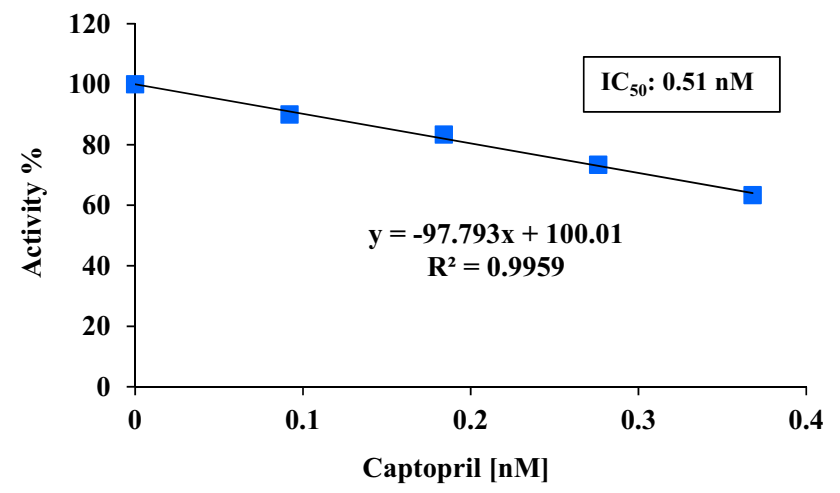

Fig. 8 The inhibition effect of Captopril on ACE from sheep lung. Four different captopril (from 0.092 to $0.368 \mathrm{nM}$ ) concentrations on ACE activity were investigated

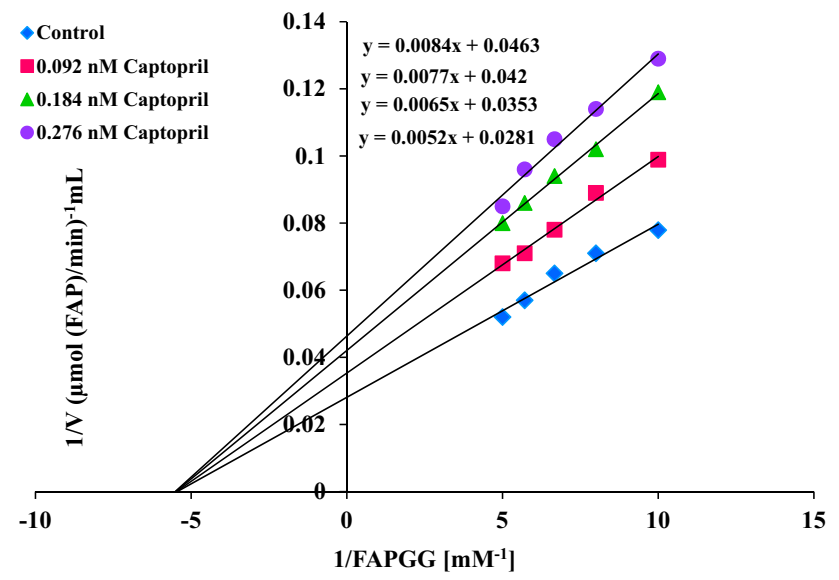

Fig. 9 Lineweaver-Burk graph with five different substrate concentrations (FAPGG) and three different Captopril concentrations used for the designation of inhibition type and $\mathrm{K}_{\mathrm{i}}$ method. Molecular weight, purity, and optimum conditions of the purified ACE enzyme were determined. ACE was successfully purified in single-step with NHS-activated Sepharose 4 fast flow column filler without using detergent, ultrafiltration, precipitation with neutral salts, dialysis. The molecular weight and purity of the purified enzyme were confirmed with the SDS-PAGE method. In this method, proteins are separated into subunits where they are denatured with SDS detergent. It was observed that the ACE enzyme purified from sheep lung was separated with SDS-PAGE into two subunits of 60 and $70 \mathrm{kDa}$. This showed that the ACE enzyme is a dimer enzyme with two sub-monomers.

ACE associated with the vascular endothelium is one of the most extensively studied enzymes both in vivo and in vitro, partly due to its contribution to the continuation of blood pressure in normal subjects and the pathogenesis of systemic hypertension in animal models and humans [10, 11]. The ACE enzyme is an important enzyme that regulates blood pressure and ACE inhibitors are generally utilized in hypertension treatment. Therefore, doing inhibitor research on pure ACE activity gives more accurate results. In future studies, many studies can be done on these inhibitors with the pure ACE enzyme.

Nowadays, the importance of ACE has increased even more. Because the ACE2 enzyme, which is a homolog of the ACE enzyme, is the entry point into the cells of violent acute respiratory syndrome coronavirus 2 (SARS-CoV-2, COVID19). ACE2, which is expressed in various human organs, catalyzes angiotensin II conversion to vasodilator angiotensin-(1-7) [61]. In studies on rodents, it has been observed that ACE inhibitors utilized in hypertension treatment increase the amount of ACE2 and therefore may increase the severity of coronavirus infections. There are concerns that ACE inhibitors increase susceptibility to the coronavirus SARS-CoV-2 virus and the severity of COVID19 disease. However, no direct studies have been found to show that ACE inhibitors increase the risk of COVID19 [62-64].

Acknowledgements This work was not supported by a project.

Author contributions VT contributed to the study conception and design. All authors contributed to the manuscript. VT, FA, and ZB performed the experiments and analyzed the data. ZB wrote the first draft of the manuscript. VT and ZB contributed to the revisions and the final draft of the manuscript. All authors read and approved the final manuscript.

Funding This work was not supported by any foundation.

\section{Declarations}

Conflict of interest The authors declare that they have no conflicts of interest. 
Ethical approval The proposed research project detailed above does not need Animal Researches Ethics Committee Approval. Date: 03/10/2019 Decision number: 2019/09.

\section{References}

1. Baradaran A, Nasri H, Rafieian-Kopaei M (2014) Oxidative stres sand hypertension: possibility of hypertension therapy with antioxidants. J Res Med Sci 19(4):358-367

2. Bakris GL, Toto RD, McCullough PA, Rocha R, Purkayastha D, Davis P (2008) Effects of different ACE inhibitor combinations on albuminuria: results of the GUARD study. Kidney Int 73(11):1303-1309

3. Yang HY, Erdös EG, Levin YA (1970) dipeptidyl carboxypeptidase that converts angiotensin I and inactivates bradykinin. Biochim Biophys Acta 214:374-376

4. Rousseau A, Michaud A, Chauvet MT, Lenfant M, Corvol P (1995) The hemoregulatory peptide N-acetyl-Ser-Asp-LysPro Is a natural and specific substrate of the $\mathrm{N}$-terminal active site of human angiotensin-converting enzyme. J Biol Chem 270:3656-3661

5. Deddish PA, Marcic B, Jackman HL, Wang HZ, Skidgel RA, Erdös EG (1998) N-domain-specific substrate and C-domain inhibitors of angiotensin- converting enzyme: angiotensin-(1-7) and keto-ACE. Hypertension 31:912-917

6. Skidgel RA, Engelbrecht S, Johnson AR, Erdös EG (1984) Hydrolysis of substance $\mathrm{P}$ and neurotensin by converting enzyme and neutral endopeptidase. Peptides 5:769-776

7. Natesh R, Schwager SL, Sturrock ED, Acharya KR (2003) Crystal structure of the human angiotensin-converting enzyme-lisinopril complex. Nature 421(6922):551-554

8. Hangauer DG, Monzingo AF, Matthews BW (1984) An interactive computer graphics study of thermolysin-catalyzed peptide cleavage and inhibition by $\mathrm{N}$-carboxymethyl dipeptides. Biochemistry 23(24):5730-5741

9. Sturrock ED, Natesh R, van Rooyen JM, Acharya KR (2004) Structure of angiotensin I-converting enzyme. Cell Mol Life Sci 61(21):2677-2686

10. Cushman DW, Cheung HS (1971) Concentrations of angiotensinconverting enzyme in tissues of the rat. Biochim et Biophy Acta (BBA)—Enzymol 250(1):261-265. https://doi.org/10.1016/00052744(71)90142-2

11. Meng QC, Oparil S (1996) Purification and assay methods for angiotensin-converting enzyme. J Chromatogr A 743(1):105-122

12. Campbell DJ (1987) Circulating and tissue angiotensin systems. J Clin Investig 79:1-6

13. Defendini R, Zimmerman EA, Weare JA, Alhenc-Gelas F, Erdos EG (1983) Angiotensin-converting enzyme in epithelial and neuroepithelial cells. Neuroendocrinology 37:32-40

14. de Andrade MCC, Di Marco GS, de PauloCastroTeixeira V, Mortara RA, Sabatini RA, Pesquero JB, Boim MA, Carmona AK, Schor N, Casarini DE (2006) Expression and localization of $\mathrm{N}$-domain ANG I-converting enzymes in mesangial cells in culture from spontaneously hypertensive rats. Am J Physiol Renal Physiol 290:F364-F375

15. Cushman DW, Cheung HS (1971) Concentrations of angiotensinconverting enzyme in tissues of the rat. Biochim Biophys Acta 250:261-265

16. Takada Y, Hiwada K, Kokubu T (1981) Isolation and characterization of angiotensin converting enzyme from human kidney. J Biochem 90:1309-1319

17. Chappell MC, Diz DI, Gallagher PE (2001) The renin-angiotensin system and the exocrine pancreas. JOP 2:33-39
18. Lattion AL, Soubrier F, Allegrini J, Hubert C, Corvol P, AlhencGelas F (1989) The testicular transcript of the angiotensin I-converting enzyme encodes for the ancestral, non-duplicated form of the enzyme. FEBS Lett 252:99-104

19. Deddish PA, Wang J, Michel B, Morris PW, Davidson NO, Skidgel RA, Erdös EG (1994) Naturally occurring active $\mathrm{N}$-domain of human angiotensin I-converting enzyme. Proc Natl Acad Sci USA 91:7807-7811

20. Kokubu T, Kato I, Nishimura K, Hiwada K, Ueda E (1978) Angiotensin I-converting enzyme in human urine. Clin Chim Acta 89:375-379

21. Casarini DE, Plavinik FL, Zanella MT, Marson O, Krieger JE, Hirata IY, Stella RC (2001) Angiotensin converting enzymes from human urine of mild hypertensive untreated patents resemble the $\mathrm{N}$-terminal fragment of human angiotensin I-converting enzyme. Int J Biochem Cell Biol 33:75-85

22. Erdös EG (1990) Angiotensin I converting enzyme and the changes in our concepts through the years Lewis K. Dahl memorial lecture. Hypertension 16:363-370

23. Casarini DE, Carmona AK, Plavnik FL, Zanella MT, Juliano L, Ribeiro AB (1995) Calcium channel blockers as inhibitors of angiotensin I-converting enzyme. Hypertension 26:1145-1148

24. Marques GD, Quinto BM, Plavinik FL, Krieger JE, Marson $\mathrm{O}$, Casarini DE (2003) N-domain angiotensin I-converting enzyme with $80 \mathrm{kDa}$ as a possible genetic marker of hypertension. Hypertension 42:693-701

25. Skidgel RA, Erdos E (1993) Biochemistry of angiotensin I-converting enzyme. In: Robertson JIS, Nicholls MG (eds) The renin-angiotensin system. Raven Press Ltd, New York

26. Brown NJ, Vaughan DE (1998) Angiotensin-converting enzyme inhibitors. Circulation 97:1411-1420

27. Hanif K, Bid HK, Konwar R (2010) Reinventing the ACE inhibitors: some old and new implications of ACE inhibition. Hypertens Res 33:11-21

28. Urh M, Simpson D, Zhao K (2009) Affinity chromatography: general methods. Methods Enzymol 463:417-438

29. Bull HB, Thornberry NA, Cordes EH (1985) Purification of angiotensin converting enzyme from rabbit lung and human plasma by affinity chromatography. J Biol Chem 260:2963-2972

30. Hooper NM, Keen J, Pappin DJC, Turner AJ (1987) Pig kidney angiotensin converting enzyme. Purification and characterization of amphipathic and hydrophilic forms of the enzyme establishes C-terminal anchorage to the plasma membrane. Biochem J 247:85-93

31. Lamango NS, Sajid M, Isaac RE (1996) The endopeptidase activity and the activation by $\mathrm{Cl}$ - of angiotensin-converting enzyme is evolutionarily conserved: purification and properties of an an angiotensin-converting enzyme from the housefly, Musca domestica. Biochem J 314:639-646

32. Quassinti L, Miano A, Bramucci M, Maccari E, Amici D (1998) Purification of swine serum angiotensin converting enzyme with high recovery of activity using lisinopril coupled to epoxy activated sepharose 6B. Biochem Mol Biol Life Sci 44(5):887-895

33. Andújar-Sánchez M, Cámara-Artigas A, Jara-Pérez V (2003) Purification of angiotensin I converting enzyme from pig lung using concanavalin-A sepharose chromatography. J Chromatogr B 783:247-252

34. Pantoliano MW, Holmquist B, Riordan JF (1984) Affinity chromatographic purification of angiotensin converting enzyme. Biochemistry 23(5): 1037-1042

35. Sabeur K, Vo AT, Ball BA (2001) Characterization of angiotensin-converting enzyme in canine testis. Reproduction 122(1):139-146

36. Holmquist B, Bünning P, Riordan JF (1979) A continuous spectrophotometric assay for angiotensin converting enzyme. Anal Biochem 95(2):540-548 
37. Bradford MM (1976) A rapid and sentive method for the quantitation of microgram quantities of protein utilizing the principle of protein-dye binding. Anal Biochem 72:248-254

38. Laemmli UK (1970) Cleavage of structural proteins during the assembly of the head of bacteriophage T4. Nature 227:680-685

39. Lineweaver H, Burk D (1934) The determination of enzyme dissociation constants. J Am Chem Soc 56:658-660

40. Grönhagen-Riska C, Fyhrquist F (1980) Purification of human lung angiotensin-converting enzyme. Scand J Clin Lab Invest 40(8):711-719

41. Erickson RH, Suzuki Y, Sedlmayer A, Song IS, Kim YS (1992) Rat intestinal angiotensin-converting enzyme: purification, properties, expression, and function. Am J Physiol 263:G466-G473

42. Eisele T, Stressler T, Kranz B, Fischer L (2012) Automated multistep purification protocol for angiotensin-I-converting-enzyme (ACE). J Chromatogr B 911:64-70

43. Bell L, Madri J (1990) Influence of the angiotensin system on endothelial and smooth muscle cell migration. Am J Pathol 137:7-12

44. Danser AH, vanKats JP, Admiraal PJ, Derkx FH, Lamers JM, Verdouw PD, Saxena PR, Schalekamp MA (1994) Cardiac renin and angiotensins. Uptake from plasma versus in situsynthesis. Hypertension 24:37-48

45. Mojallal-Tabatabei Z, Asoodeha A, Housaindokhta MR, Chamani J (2013) Purification and biochemical characterization of angiotensin I-converting enzyme (ACE) from ostrich lung: The effect of 2,2,2-trifluoroethanol on ACE conformation and activity. Process Biochem 48:1091-1098

46. Hooper NM, Turner AJ (1987) Isolation of two differentially glycosylated forms of peptidyl-dipeptidase A (angiotensin converting enzyme) from pig brain: a re-evaluation of their role in neuropeptide metabolism. Biochem J 241:625-633

47. Howard TE, Shai S-Y, Langford KG, Martin BM, Bernstein KE (1990) Transcription of testicular angiotensin-converting enzyme (ACE) is initiated within the 12th intron of the somatic ACE gene. Mol Cell Biol 10:4294-4302

48. Bernstein KE, Khan Z, Giani JF, Cao DY, Bernstein EA, Shen $\mathrm{XZ}$ (2018) Angiotensin-converting enzyme in innate and adaptive immunity. Nat Rev Nephrol 14:325-336

49. Miano A, Quassinti L, Maccari E, Murri O, Amici D, Bramucci M (2003) Purified angiotensin converting enzyme from Rana esculenta ovary influences ovarian steroidogenesis in vitro. J Physiol Biochem 59(4):269-276

50. El-Dorry HA, Bull HG, Iwata K, Thornberry EH, Soffer RL (1982) Molecular and catalytic properties of rabbit testicular dipeptidyl carboxypeptidase. J Biol Chem 257:14128-14133

51. de Andrade MCC, Affonso R, Fernandes FB, Febba AC, da Silva IDCG, Stella RCR, Marson O, Jubilut GN, Hirata IY, Carmona AK, Corradi H, Acharya KR, Sturrock ED, Casarini DE (2010) Spectroscopic and structural analysis of somatic and N-domain angiotensin I-converting enzyme isoforms from mesangial cells from Wistar and spontaneously hypertensive rats. Int J Biol Macromol 47(2):238-243

52. Aragão DS, de Andrade MCC, Ebihara F, Watanabe IK, MagalhŃes DC, Juliano MA, Hirata IY, Casarini DE (2015)
Serine proteases as candidates for proteolytic processing of angiotensin-I converting enzyme. Int J Biol Macromol 72:673-679

53. Basi Z, Turkoglu N, Turkoglu V, Karahan F (2019) In vitro effect of ethyl acetate, butanol and water extracts of Juniperus excelsa Bieb. on angiotensin converting enzyme purified from human plasma. Chem Pap 73:2525-2533

54. Bas Z, Turkoglu V, Goz Y (2021) Investigation of inhibition effect of butanol and water extracts of Matricaria chamomilla L. on angiotensin-converting enzyme purified from human plasma. Biotechnol Appl Biochem. https://doi.org/10.1002/bab.2106

55. Métayer S, Dacheux F, Guérin Y, Dacheux JL, Gatti JL (2001) Physiological and enzymatic properties of the ram epididymal soluble form of germinal angiotensin I-converting enzyme. Biol Reprod 65:1332-1339

56. Basi Z, Turkoglu V (2018) Purification of angiotensin-converting enzyme from human plasma and investigation of the effect of some active ingredients isolated from Nigella sativa $\mathrm{L}$. extract on the enzyme activity. Biomed Chromatogr 32(5):4175

57. Abdulazeez Mansurah A, Aimola IA, Annette RO, Abdullahi S (2013) Isolation, partial purification and characterization of angiotensin converting enzyme (ACE) from rabbit (Oryctolagus ciniculus) lungs. Am J Drug Discov Dev 3:120-129

58. Basi Z, Turkoglu V (2019) In vitro effect of oxidized and reduced glutathione peptides on angiotensin converting enzyme purified from human plasma. J Chromatogr B Analyt Technol Biomed Life Sci 1104:190-195

59. Mendelsohn FA, Csicsmann J, Hutchinson JS (1981) Complex competitive and non-competitive inhibition of rat lung angiotensin-converting enzyme by inhibitors containing thiol groups: captopril and SA 446. Clin Sci 61:277s-280s

60. Baudin B, Bénéteau-Burnat B (1999) Mixed-type inhibition of pulmonary angiotensin I-converting enzyme by captopril, enalaprilat and ramiprilat. J Enzym Inhib 14(6):447-456

61. Santos RAS, Sampaio W, O., Alzamora A. C., Motta-Santos, D., Alenina N., Bader, M., \& Campagnole-Santos, M. J. (2018) The ACE2/angiotensin-(1-7)/MAS axis of the renin-angiotensin system: focus on angiotensin-(1-7). Physiol Rev 98:505-553

62. Nicholls J, Peiris M (2005) Good ACE, bad ACE do battle in lung injury SARS. Nat Med 11(8):821-822

63. Diaz JH (2020) Hypothesis: angiotensin-converting enzyme inhibitors and angiotensin receptor blockers may increase the risk of severe COVID-19. J Travel Med. https://doi.org/10.1093/jtm/ taaa041

64. Ni W, Yang X, Yang D, Bao J, Li R, Xiao Y, Hou C, Wang H, Liu J, Yang D, Xu Y, Cao Z, Gao Z (2020) Role of angiotensinconverting enzyme 2 (ACE2) in COVID-19. Crit Care 24:422

Publisher's Note Springer Nature remains neutral with regard to jurisdictional claims in published maps and institutional affiliations. 